\title{
KIRSTEN HASTRUP
}

\section{RADIKAL FORTOLKNING}

\author{
Humanistisk teori ved årtusindskiftet ${ }^{1}$
}

I renæssancen opstod en ny menneskeforståelse, som frigjorde mennesket fra sin faste plads i middelalderens guddommelige orden. Hermed banedes vejen for en videnskab om mennesket og det menneskelige som noget i sig selv. Hvad enten vi fokuserer på menneskelige fællesskaber eller på enkelte menneskelige udtryk, så er de menneskelige videnskaber stadig baseret på en forestilling om det ,frie“ menneske. At der er grader af frihed er selvklart, men begrænsningerne er ikke hverken gudgivne eller naturbestemte.

Et af de mest kendte programskrifter for renæssancens nye menneskesyn er Giovanni Pico della Mirandolas skrift Om Menneskets Vardighed (1486). Pico della Mirandola (1463-1494) studerede ved de bedste universiteter i Italien, og det nævnte skrift opsummerer hans forestilling om menneskets særstilling i universet, fordi det i modsætning til andre skabninger har frihed til at realisere sine muligheder og ansvarlighed for at gøre det. Menneskets særstilling begrundes faktisk indledningsvist i skabelsesberetningen, hvor Gud først skabte verden uden om mennesket: „Men da han havde fuldført sit værk, ønskede skaberen at der måtte være nogen til at gennemtænke et så stort værks fornuft, elske dets skønhed og beundre dets storhed“ (Nielsen 1996:48-9). Derfor skabte han mennesket. Pico henviser til de klassiske filosoffer, såvel som til gældende teologi, og på den baggrund fremstiller han mennesket som en størrelse, der kan gøres til genstand for særlig (videnskabelig) interesse.

Genopdagelsen af den klassiske verdens bedrifter betød også, at historien genopstod som et menneskeligt produkt. Man blev opmærksom på, at fortiden var adskilt fra og anderledes end nutiden, og hvad enten man tolkede dette som en udvikling eller et forfald, så lå der heri kimen til en radikalt anderledes tænkning om tid og historie end den middelalderlige. Den idé vinder nu frem, at mennesket ikke blot efterligner en orden, men skaber en særlig orden, som ikke har noget absolut forbillede, og derfor er „kunst“; i den forstand bliver mennesket ansvarligt for sin egen verden. Igen er det værd at lytte til Pico della Mirandola, som skriver om skabelsen af mennesket, at den faderlige almagt måtte tildele den sidste skabning det bedste af alt, for at den kunne rumme det hele:

Derfor bestemte den bedste af alle kunstnere til sidst at det væsen som han ikke kunne give noget specielt, skulle have del i alt hvad han havde tildelt hver enkelt af de øvrige skabninger. Derfor godtog han mennesket som et værk af ubestemt natur, satte det midt i verden og talte således: 'Vi har hverken givet dig en bestemt plads, en speciel skikkelse eller en 
særlig funktion, Adam, for at du efter dit eget ønske og din egen beslutning kan opnå og besidde den plads, den skikkelse og den funktion du selv måtte $ø$ nske. De $\emptyset$ vrige skabningers natur begrænses og defineres af love, der er foreskrevet af os. Du holdes ikke tilbage af nogen uovervindelige skranker, men skal selv bestemme din natur i overensstemmelse med din egen frie vilje, i hvis varetægt jeg har overgivet dig. Jeg har sat dig midt i verden, for at du derfra lettere kan se, hvad der findes i verden omkring dig. Vi har hverken skabt dig som et himmelsk eller et jordisk, hverken som et dødeligt eller et udødeligt væsen, for at du som din egen skulptør og kunstner med frihed og ære kan skabe dig den form, du sætter højest. Det skal stå i din magt at udarte til lavere former, der er dyriske; det skal stå i din magt efter din egen viljes beslutning at hæve dig til højere former, som er guddommelige' (Nielsen 1996:49).

Mennesket rummer således alle muligheder, og det er og bliver en væsentlig del af det humanistiske projekt at fastholde mennesket som ansvarligt - ikke nødvendigvis hvert enkelt lille menneske, der kan være underlagt magtformer og samfundssystemer, der netop opretholdes ved, at magthaverne fratager den enkelte både sine muligheder og sit ansvar. Ansvaret for historien knytter sig dog stadig til mennesker også i form af magthavere, ikke til abstrakte samfundssystemer eller naturlige lovmæssigheder.

Når jeg her taler om humanismen i generelle vendinger i en artikel, der primært skulle dreje sig om antropologiens status ved årtusindskiftet, så er det ikke tilfældigt. For det første er det et kendetegn ved humanismen, at den altid - a priori - må basere sig på en antropologi. For det andet mener jeg, at den ,afsnøring“ af en videnskabelig antropologi (og alle mulige andre videnskabelige discipliner) fra det almene humanistiske felt, som har fundet sted i det nittende og tyvende århundrede, er ved at være udtømt for energi; specialiseringen har nået et punkt, hvor samtalen er lige ved at gå i stå, selv inden for de enkelte fag. Jeg ser det derfor som et væsentligt strategisk projekt her ved årtusindskiftet at sammentænke hele det videnskabelige felt igen, inklusive samfunds- og naturvidenskaberne, for måske at genopbryde det på nye måder. Her skal jeg dog argumentere ud fra den humanistiske synsvinkel.

Videnskabens lange vandring fra renæssance over oplysning og romantik til modernisme og dens udløbere er forudsætningen for, at vi i dag kan se konturerne af et nyt sammenhængende vidensprojekt for de humanistiske discipliner. Det er et vidensprojekt, der stadig er baseret på en strategisk afstand mellem empiri og teori, men som samtidig hviler på en erkendelse af menneskets centrale placering i begge felter. Afstanden er en forudsætning for at vi kan bidrage til den kollektive bevidsthed om verdens indretning med mere end $\varnothing$ jebliksbilleder, det vil sige med en egentlig teoretisk indsigt, der rummer såvel forståelse og forklaring som praksis.

Teorier er fortættede udsagn om verden, som rummer forslag til, hvordan visse sammenhænge kan forstås. Historien kan siden indhente nogle af disse forslag, som humanister hele tiden lægger frem til samfundets frie afbenyttelse. Den fortættede viden om menneskelige forhold rummer en ofte uerkendt historisk ,,energi“ “ $i$ den forstand, at verden jo altid delvist bliver, som vi forestiller os den. Selvom ikke alle muligheder står åbne og langt fra er jævnt fordelt over kloden, så afhænger ethvert menneskes eller ethvert samfunds næste skridt på historiens vej jo en hel del af, hvilke forestillinger man gør sig om mulighederne. Det er til dette forestillingsrum, at humanvidenskaberne hele tiden bidrager. Også oldtidsvidenskaberne kan på den måde bidrage afgørende til fremtiden.

De sammenhænge, som videnskaben foreslår, kan ikke ses, men de kan anes og dernæst artikuleres i et videnskabeligt sprog, der allerede er et skridt væk fra kendsgernin- 
gerne, og som altid introducerer sine egne forudsætninger og analytiske konstruktioner af tid og rum. For eksempel indebærer forskellen på kausale, funktionelle og strukturelle sammenhænge (der konstituerer forskellige mulige teorier om „samme“ forhold) helt forskellige konstruktioner af og med tiden. Kausalitet forudsætter en fremadrettet tid; noget er årsag til noget andet, der som virkning følger efter årsagen. Funktionalitet fremhæver det modsatte: et forhold bidrager „baglæns“ til at opretholde en allerede given orden. Og strukturelle sammenhænge understreger samtidighed og i nogen grad tidløshed. I alle tilfælde er der tale om et valg af perspektiv, en konstruktion af relationer, der ikke er givet af objektet selv, men findes imellem subjekt og objekt, der hvor betydning skabes, og verden genopstår i fortættet form.

Når sammenhængene ikke kan ses, eller overhovedet siges at være objektet iboende, så kan de naturligvis heller ikke bevises. Men de kan og skal, som tidligere nævnt, sandsynliggøres ved hjælp af et argument, der helst skal være mere overbevisende end det, Holberg lagde i munden på Erasmus Montanus, som nåede til den konklusion, at Morlille var en sten. Uden at forstene objektet i påståede naturlige ontologier skal vi fastholde realiteten i det menneskelige vilkår og gøre den til genstand for en transcendent forståelse. Med andre ord, hinsides valget mellem oplysningens ideal om rationalitet, fremskridt og naturlige sammenhænge og romantikkens fortabelse i det enestående skal vi nu finde en tredje vej, der kan vejlede os i at sige noget egentlig nyt om verden og således leve op til vores videnskabelige ansvar.

\section{Nye teorier}

Spørgsmålet er grundlæggende, hvordan vi får det teoretiske projekt knyttet sammen dels med den praktiske erfaring med menneskeligheden, dels med erkendelsen af humanismens flydende objekt. En del af svaret finder vi ved at se på ,det teoretiske“ selv, og forstå dets natur. Etymologisk peger ,teori“ mod „en betragtning“, og som vi har set, er dette i visse perioder blevet taget meget bogstaveligt som det faktisk sete. Betragtninger omfatter imidlertid meget andet end det og kan umiddelbart rumme forskellige forslag til forståelse af usynlige sammenhænge. Alle mennesker gør sig overvejelser over verden og fremsætter betragtninger over dette og hint. Videnskabelige teorier er betragtninger, der adskiller sig fra de almene betragtninger ved at være baseret på særligt systematiske og forpligtende unders $\varnothing$ gelser af konkrete forhold; derfor har de større holdbarhed end den linde strøm af småbetragtninger, der udveksles mellem mennesker i dagens løb, men de er i øvrigt grundlæggende af samme art - fordi de også fremsættes af mennesker.

Vi kommer her frem til en meget enkel sandhed om teorier, nemlig at de simpelthen er sætninger, som foreslår særlige fortolkninger af verden, og som i deres natur både transformerer og reducerer den virkelighed, de drejer sig om. Som sproglige udsagn forholder teorierne sig til verden ligesom en målestok forholder sig til det målte; de får væsentlige ting med, men kan aldrig rumme det hele. Tommestokken er bedre til at måle lige linier end til at måle de tommelfingre, der har givet den navn. På samme måde er sproget bedre til at repræsentere det sagte end det følte; men det kan alligevel sige noget væsentligt også om følelser, blandt andet fordi disse indgår i sprogets (for-)historie, hvor de ligger som en uerkendt del af ordenes værdiindhold. 
Teorier er sætninger. Alle humanistiske teorier er fælles om dette sproglige grundvilkår, men opfattelsen af den teoretiske målestok splitter til gengæld forskernes verden $\mathrm{i}$ (mindst) to dele. Charles Taylor har foreslået en distinktion mellem designative og ekspressive teorier (Taylor 1985:218f.; se også Hastrup 1995). De førstnævnte er relativt ligefremme i deres udpegning af visse kvaliteter ved objektet, der som regel er naturaliseret; det vil sige, at det tillægges naturlige grænser og objektiv eksistens - eller ontologisk status. Den slags teorier, eller den dimension af den teoretiske tænkning kan samles under betegnelsen korrespondensteorier, og de har været fremherskende i hele den modernistiske fase. Korrespondensprincippet indebærer, at teorierne er blevet anset for direkte at afspejle virkeligheden, sådan som den objektivt foreligger. Det gælder således for de store klassiske teorier (,-ismerne“), at de er baseret på en antagelse af, at verden umiddelbart kan afbildes eller afspejles i teorierne. Det var denne afspejlingsforestilling, som modernismekritikken gjorde op med under mange forskellige bannere. Kritikken resulterede blandt andet $\mathrm{i}$ en konstruktionisme, der gik ud på, at forskerne var med til at konstruere verden ved at omslutte den i specifikke begreber. Konstruktionismen har haft en vis betydning, men den ender nemt i temmelig absurde forestillinger om, at verden kun er, som vi nu kan beskrive den. Hermed tillægger man i mine øjne både „os“ og sproget al for stor betydning.

Der er imidlertid en anden mulighed, der står åben for os, og den knytter sig til en ny bevidsthed om det teoretiske projekt som i bund og grund ekspressivt. Ekspressive teorier antages ikke at afspejle verden, men at udtrykke særlige aspekter ved den, aspekter der ellers ikke finder udtryk. Det teoretiske udtryk tilføjer således noget til verden; det bidrager i sin egen ret, men hverken afbilder eller erstatter den.

Det er min opfattelse, at de humanistiske videnskaber i særlig grad har noget at vinde ved en bevidst udnyttelse af dette ekspressive teoretiske potentiale. Den tilføjelse til verden, som teorierne rummer, giver nemlig mulighed for at „svare“ verden på en ny måde. Og vi behøver ikke at legitimere vores videnskabelige bestræbelse med andet end netop det: at vi tilføjer noget til verden, fordi vi udtrykker noget, der ellers ikke udtrykkes. Nytten underordnes nyheden.

Denne form for teoretisk udtryk eller artikulation bryder radikalt med den klassiske (oplysnings-) forståelse af videnskab som ,opklarende“; i denne opfattelse var det videnskabens opgave at afsløre objektets natur, eller altså at opklare verdens gåder ved simpelthen at blotlægge naturen, herunder menneskets, samfundets, kulturens, historiens, og kunstens natur. Det var den opfattelse, der blev omsat og perfektioneret i autopsien som den ultimative videnskabelige metode (jf. Hastrup 1990). I modsætning til denne forestilling om, at det menneskelige har en natur, som vi en gang for alle kan fastslå, hvis vi indstiller optikken rigtigt, så foreslår Donald Davidson (1984), at vi betragter vores projekt som et spørgsmål om ,radikal fortolkning“. Den radikale fortolkning rummer nemlig muligheden for at tilføje noget nyt til verden, snarere end at opklare det allerede givne og det i objektet iboende. Hermed kan man umiddelbart tilgodese den indsigt, at objektet for netop de humanistiske videnskaber ikke er uforanderligt og uafhængigt af den teoretiske interesse.

Dette sidste punkt indebærer også, at det ekspressive syn på den teoretiske praksis kun holder, hvis vi opgiver den metafysiske realisme, som går ud fra, at der er én, absolut sandhed at fortælle om verden. Det gælder ikke længere, og kan slet ikke gælde det menneskelige objekt. Men dette betyder på den anden side ikke, at der er frit slag på alle 
hylder, sådan som en ekstrem konstruktionisme ville hævde det. Teorier er jo nemlig i kraft af deres sproglige udtryk og deres reduktive kraft både flyttelige og offentlige. Det betyder, at de lægger sig blot for uenighed og afprøvning $\mathrm{i}$ andre sammenhænge. Selvom tommestokken først tog mål af tommelfingre, så kan den jo også bruges til at måle hele menneskers højde. Tilsvarende kan en teori om, hvordan visse kulturelle forestillinger i 1700-tallets Island gav anledning til en særlig udvikling af det islandske samfund, jo muligvis give anledning til en mere omfattende teori om sammenhænge mellem kultur og historie i almindelighed, der kan „måle" andre udviklinger andre steder.

Gyldigheden af humanistiske teorier hænger nemlig i høj grad på, om de kan deles, det vil sige om de kan give mening ud over den meget specifikke sammenhæng, de blev til af. Det kan de kun, hvis de er rationelt acceptable, eller med andre ord, hvis de er konsistente med erfaringen. $\mathrm{Og}$ vi må her huske på, at erfaring er noget andet end sprog; der er store dele af den menneskelige viden, der ligger uden for sproget, og som derfor udfordrer sprogets kategorier, men aldrig udtømmer dem. Rækkevidden og betydningen af enkelte teorier er således snævert forbundet med omfanget af den fællesmenneskelige erfaring, som de ,rammer“. De teorier, der bliver stående længst, er de forslag om sammenhænge, der bedst modstår de historisk betingede ændringer i det humanistiske objekt.

Acceptabilitet er ikke kun et spørgsmål om en simpel flertalsafgørelse; som alle ved, er ,flertallet“ ofte en funktion af særlige institutionelle forhold, eller af særlige magtforhold. Der er ikke tale om at skulle lade flertallet afgøre, hvad der er rigtigt, og hvad der er forkert, men om at holde mulighederne åbne for andre forståelser end flertallets, ved hele tiden at efterprøve argumenterne og teoriernes konsistens med erfaringen - herunder den fællesmenneskelige erfaring med at forstå sin egen erfaring på nye måder, enten ved hjælp af nye begreber, eller ved at "genkende" erfaringer, man endnu ikke har gjort sig, i de foreslåede udsagn. Megen psykoterapi udnytter den første strategi: at foreslå nye begreber, der kan rumme de kaotiske erfaringer. Omvendt er det i høj grad forbundet med kunsten at levere „genkendelse“ af det uprøvede. Humanistisk videnskab må nødvendigvis rumme begge strategier.

Hvis pragmatismen, som knytter sine filosofiske overvejelser til konkrete samfundsforhold snarere end til formal-logiske problemstillinger, på den ene side synes at glide mod utilitarismen, derved at de umiddelbart nyttigste teorier er dem, der først accepteres, og på den anden side synes at tendere mod flertalsdiktatur, så er det altså ikke nødvendigvis en del af det gyldighedskriterium, jeg her opstiller. De rationelt acceptable udsagn i de humanistiske videnskaber er dem, der tager menneskeligheden helt alvorligt, som på en gang inkorporeret historie og transcendens.

Selvom teorier ikke er synonyme med verden og trods det, at de i princippet er subjekt-henvisende - fordi der ikke er nogen viden, uden at der er (mindst) én, der ved - så er der grænser for friheden. Al humanistisk forskning må overbevise ved hjælp af et argument, og man vil kunne se nu, at det blandt andet skyldes dens kvalitet som radikalt fortolkende snarere end blot opklarende. Fortolkninger skal der tales for, og der skal tales til nogen, nemlig i første omgang til det videnskabelige kollektiv, som er det sted, de nye teorier skal forelægges og afprøves ved den grad, de kan accepteres som udtryk for en kendt eller en mulig erfaring. Verden består af en række svar, vi til stadighed skal finde nye spørgsmål til, og det er bestemt ikke alle spørgsmål, det giver mening at stille.

Teorier, og de er jo som næunt blot sætninger, udtømmer aldrig mulighederne for fortolkning, fordi de netop ikke handler om afspejling eller direkte referens, men om til- 
føjelse af ny betydning. I denne ekspressive forståelse af teorierne får også det teoretiske sprog ny betydning; det er ikke blot et objektivt klassificerende, men et metaforisk afsøgende sprog, der ikke opklarer men fortolker verden på radikalt nye måder.

\section{Helhed og sammenligning}

Det opg ør med de stivnede begreber om verden, som har fundet sted i de seneste tiår, har medført en usikkerhed omkring forståelsen af det analytiske objekt. Ikke desto mindre må et sådant analytisk objekt stadig forudsættes, hvis det teoretiske arbejde skal give mening. I antropologien gav opløsningen af kulturbegrebet anledning til et meget kritisk spørgsmål om antropologiens videnskabelige status, fordi den ramte et centralt punkt i den antropologiske tradition. Kulturer kunne ikke længere ses som essenser, men kun som analytiske implikationer af selve det videnskabelige projekt, eller i en vis forstand som resultater af den etnografiske beskrivelse selv.

Problemet er ikke begrænset til antropologien, men er måske igen særlig tydeligt der, fordi det kritiske spørgsmål indebar en problematisering af den holisme, som var et klassisk etnografisk princip; ethvert kulturelt eller socialt fænomen måtte forstås i sin helhed, inden for rammerne af en veldefineret kulturel kontekst. Men hvis helheder kun er noget, der skabes i skriften, så er det naturligvis tvivlsomt, om man kan rejse en (empirisk) videnskab på det grundlag. Men det er også tvivlsomt, om man kan afskaffe en helhedstænkning, der stadig kan sætte rammer om forståelsen. Selvom vi har afskaffet den metafysiske realismes påstand om empirisk afgrænselige kulturer, så forudsætter den ,interne realisme“ (Putnam 1990) stadig en forestilling om rimeligt afgrænselige analytiske objekter. Når de skal være rimeligt afgrænselige, så betyder det for det første, at de skal have en eller anden overensstemmelse med virkeligheden (hvor der jo for eksempel findes kulturelle forskelle, selvom der ikke er kulturel essens), eller rettere sagt, den del af virkeligheden, man vil undersøge, og for det andet, at de afgrænses i forhold til metodens rækkevidde. Objekt og projekt er forbundne i en holisme, der ikke er en (kulturel) betydningsholisme, men en teoretisk holisme, der medtænker sine egne sandhedsbetingelser. Dette skift i holismens forankring er korreleret med en udvikling af videnskaben fra oplysningens opklaring til nutidens radikale fortolkning. Med dette skift introduceres der et spring mellem det empiriske objekt og det videnskabelige projekt.

Det analytiske objekt kan konstruerers i forskellig målestok. Der ligger ingen forudfattet mening om, at det må udgøres af kulturer, eller lignende enheder. Men samtidig må vi give afkald på klassifikationsprojektet og dets forestilling om en én-til-én overensstemmelse mellem verden og videnskaben, eller med andre ord mellem kulturen og repræsentationen. Uanset objektets målestok vil det teoretiske projekt indebære en kondensering, eller en fortætning af empirien, der transformerer og reducerer den. Fortætningen omfatter naturligvis kun de dele af verden, som ikke filtreres fra i vores konstruktion af objektet.

Hvis vi i globaliseringens navn konstruerer objektet „globalt“ og på den måde gør hele verden til genstand for vores interesse, så får vi meget lidt at vide om forskelle, og ikke mindst udgrænses hele den menneskelige erfaring med det globale. Erfaring gøres af subjekter, der lever bestemte steder og er motiveret til særlige handlinger. Når vi taler om et ,globalt“ analytisk objekt, så forudsættes det imidlertid, at det skal analyseres $i$ sin 
helhed. Den eneste helhed, vi kan analysere globalt, er netop det, der flyder ud over det hele, det, der forbinder, det, der i virkeligheden definerer objektet selv. Opdagelse, definition og repræsentation falder stadig sammen, ligesom i det klassiske kulturbegreb.

Nødvendigheden af at opstille et analytisk objekt er altså ikke ophævet, selvom vi taler om globalisering og altings sammenhæng med noget andet. Tværtimod leder dette blot til fornyet erkendelse af, at der næppe findes noget endeligt afgrænseligt empirisk objekt for humanistisk videnskab; den menneskelige aktivitet sprænger altid disse grænser. Til gengæld kan vi så på baggrund af videnskabelige overvejelser identificere helt rationelle analytiske objekter.

Denne analytiske „objektivering“ resulterer ikke i konstruktionisme. Selv de mest fasttømrede humanistiske objekter - kultur, sprog, religion, litteratur, historie, kunst, bevidsthed - er opstået som teorier. Der er tale om teorier på et højt abstraktionsniveau, men alligevel vil ingen vel benægte disse forholds realitet. Som diskrete enheder er de udtryk for „ontologiske dumpninger“; det vil sige, at de henviser til kategorier, der først opstod som en måde at forstå verden på, altså et epistemologisk forhold, men som i gentagen brug fik selvstændigt liv (jf. Rapport 1997). På den måde er de blevet virkelige. Meget få humanistiske projekter har siden renæssancen haft en så høj eller omfattende ambition, at disse „første“ teorier om menneskelige grundvilkår kunne anfægtes. Man har nøjedes med mindre, som for eksempel at sætte spørgsmålstegn ved nogle af de elementer, der til enhver tid er indgået i de teoretiske fortætninger. De mest omfattende teorier har altid givet næring til mindre omfattende teorier.

De ontologisk dumpede forskelle i verden, såsom forskellen mellem kultur og natur, eller mellem historie og litteratur, er udtryk for tankens indgriben i verden, eller måske mere præcist for sprogets infiltrering af ontologien. Men det betyder ikke, at de forhold, sproget beskriver, er konstruerede, ej heller, at den samlebetegnelse, de får, er uden sammenhæng med virkeligheden. For at ordene kan give mening, må de „samle“ netop de forhold, om hvilke mennesker intuitivt ved, at de deler visse kvaliteter. „Mening“ kan ikke være privat; den er altid social, fordi sprog henvender sig til nogen. Også her er der tale om et kriterium af rationel acceptabilitet.

Som teoretiske enheder er alle humanistiske objekter naturligvis åbne for kritik og diskussion, og for historisk nedslidning. Men som vi kan se det af de nævnte eksempler, er der faktisk teoretiske konstruktioner, som modstår århundreders slid; det gør de på grund af deres rummelighed og på grund af deres overensstemmelse med almen erfaring. De er dog aldrig helt urørlige; de udfordres faktisk konstant af de humanistiske forskere, der til enhver tid konfronterer sig selv med nye måder at forstå verden på og nye metoder til at tilegne sig det historiske potentiale.

I de senere år er én af udfordringerne kommet fra den metodologiske individualisme, der i samfundsvidenskaberne har afløst den tidligere dominerede forestilling om samfundets dominans over den enkelte. Det er en ,individualisme“, der paradoksalt nok har bidraget til en genetablering af det antropologiske objekt efter dekonstruktionen af kulturbegrebet. Den deraf følgende interesse for ,selvet“ endte ganske vist for nogle i en ekstrem og uproduktiv narcissisme, men for andre blev den vejen tilbage til en større helhed, fordi selvbevidstheden medførte en fornyet opmærksomhed over for den måde, hvorpå selvet var motiveret og orienteret (Cohen 1994). Og langt fra at ende i det private førte dette tilbage til et fællesskab, der deler sprog, billeder, og forestillinger om hinanden, uden af den grund nødvendigvis at tillægge dem samme betydning eller at være fanget $\mathrm{i}$ 
mentale fængsler. Og det er lige præcis det nye: at selvom man deler kulturelle forestillinger, så knytter man erfaringsbestemte billeder til dem. Det har antropologien dokumenteret i minutiøse detaljer for såvel mikrosamfund (f.eks. Rapport 1993), som mere komplekse, pluralistiske samfund (f.eks. Barth 1993).

Selvom vi bliver tættere ved den specifikke erfaring, så ender det ikke nødvendigvis i private jeremiader, der ikke tillader én at se forskel på teori og terapi. Det er jo et temmelig gennemgående træk i det menneskelige samfund, at man lever sammen i sociale fællesskaber. Dette empiriske forhold ledsages af den teoretiske indsigt, at mennesker også orienterer sig i forhold til hinanden, og i forhold til de rammer, der til enhver tid udgør horisonten for deres muligheder, fysisk, epistemologisk og moralsk: kort sagt historisk. Horisonter flytter sig naturligvis, men der findes ikke sociale handlinger og kulturelle begivenheder uden en eller anden forestilling om rammer. Det er disse forestillinger om rammer, eller de handlingsrum, de skaber for den enkelte og for kollektivet, der udgør de nye (teoretisk konstruerede) enheder, som vi må studere fra forskellige vinkler. Disse rum udgør den empiriske forankring af de analytiske objekter, vi konstruerer for os selv. Jeg har i anden sammenhæng kaldt dem ,handlingsteatre“ (Hastrup n.d.), men navnet er mindre vigtigt end erkendelsen af deres flydende kvaliteter.

Det humanistiske projekt, af større eller mindre målestok, er altid i en vis forstand komparativt. Hele videnskabeliggørelsen af det menneskelige i det nittende århundrede drejede sig meget bogstaveligt om at fastslå dette, ikke mindst hvad angik de ikke-tekstbaserede videnskaber. Christian Jürgensen Thomsen, som viede sit liv til Nationalmuseet, siger således i 1846:

\begin{abstract}
Oldgranskningens Virksomhed, forsaavidt den gaaer ud paa at opklare Menneskeslægtens forhistoriske Tilstand, er væsentlig naturhistorisk, [mens] Ethnographien, der hidtil har været altfor meget tilsidesat, danner saa at sige en Overgang fra Naturhistorien til Historien. [...] der er ingen Tvivl om, at ligesom en ny Videnskabsgreen aabnedes ved at Man henvendte Opmærksomheden paa den comparative Anatomie, saaledes er nu den comparative Archæologie i Begreb med at vinde Erkjendelse. Man har for meget overseet, at det samme Culturtrin og ei alt for forskjellige climatiske Forhold bringer Mennesket til at bruge de samme Midler til at afhjælpe sine Fornødenheder. Ei heller har Culturens Gang i den senere Periode været saa overordentlig forskjellig i de forskjellige Lande, omendskjønt til forskjellige Tider (citeret efter Jensen 1992:313).
\end{abstract}

Komparation forudsætter, at der kan identificeres nogle meningsfulde enheder, som så kan sammenlignes, hvorefter der kan udddrages en generel lære; en sådan enhed var Culturen for Thomsen.

I antropologien, der i Danmark startede som den „Ethnographie“, Thomsen nævner, har sammenligning altid været et omdrejningspunkt i selvforståelsen. Den har været opfattet forskelligt til forskellige tider og drejet sig om en sammenligning af enten dele eller helheder, begreber eller kulturer, af enten fortidige eller nutidige kulturmønstre, men den var der altid som en del af den faglige identitet. Sammenligning var en metode til at måle forskelle i tid - som for eksempel forskellige stadier af udvikling, vækst, eller mentalitet - eller oftere forskelle i rum - som forskellige kulturer, samfund, institutioner eller begreber i den etnografiske nutid. I dette århundrede er denne komparative modus blevet næret af feltarbejdstraditionen og den holistiske ambition.

Med afviklingen af det klassiske objekt forlød det, at sammenligningen ville gå samme vej - ud af billedet. Men det er ikke en naturlig følge af den historiske udvikling. For 
det første var de påstået empiriske objekter altid teoretiske, og for det andet var sammenligning kun mulig ved netop at fastholde en teoretisk konstant. En sammenligning af kulturer forudsætter et fast begreb om „kultur“, i forhold til hvilken man kan måle forskelle. Sammenligning har derfor aldrig været en direkte konfrontation af forskelle; den er altid foregået via et tredje punkt, uden hvilket sammenligning ikke giver mening. Via dette tredje punkt har enhver kulturbeskrivelse altid været implicit komparativ, fordi beskrivelsens præmis har været en underforstået anerkendelse af (teorien om) kultur. Når det drejer sig om menneskelige forhold, er det derfor så meget vigtigere at gøre sig dette tredje punkt klart, som det ikke er et naturligt fixpunkt, men et begreb, eller en teori, der er forudsætningen for selve den videnskabelige undersøgelse af „objektet“.

Den teoretiske holisme, der har afløst betydnings- eller funktionsholismen, forhindrer således på ingen måde det sammenlignende humanistiske projekt. Tværtimod er der tale om en holisme, der bryder med den naturalisme, der synes opbrugt i forståelsen af menneskers liv og vilkår. Den teoretiske holisme giver derfor ny betydning til det projekt, der i første række hviler på en antropologi, eller en teori om det fællesmenneskelige, som er den implicitte konstant i undersøgelsen af menneskelivets mangfoldige tematikker, der omsættes i handling og historie.

\section{Realistiske forestillinger}

Det er umuligt at hævde, at forskeren står helt uden for sit materiale, eller at han eller hun blot er en neutral observat $ø$ r af verden, som derefter kan beskrives i objektive begreber. Men verden bliver jo ikke mindre virkelig af, at vi er en del af den. Den verden, vi er en del af, er tværtimod al den verden, vi kan få fat i, og humanister må slå sig til tåls med, at netop det at være ,i berøring med“ virkeligheden er den fornemste garant for en realistisk videnskab.

Den klassiske dualisme mellem subjekt og objekt resulterede i en procedural rationalitet, hvor det gjaldt om at få instrumentel kontrol over objektet. Videnskaben voksede frem på de præmisser, og oplysningens verdensbillede fastholdt forskerne i en forestilling om, at virkelighedens essens var skjult bag en tåge af skyggebilleder. Hvis bare vi kunne sprede tågerne, kunne vi finde frem til den egentlige virkelighed. Den klassiske forestilling om en metafysisk realisme i videnskaben var baseret på dette. Som nævnt ovenfor var projektet $\mathrm{i}$ denne forståelse at opklare det af naturen givne: altings essens. Det var specielt naturvidenskaberne, der blev drevet frem af denne forestilling, mens humanvidenskaberne gennem tiderne fik lov også at lege med de skiftende skygger: billederne på væggen, tegnene i leret, heltene i litteraturen, tonerne i symfonier.

Tiden er kommet til at se sammensmeltningen af essens og billede i øjnene, og til at forlade opklaringens ideal til fordel for den radikale fortolkning, som introduceredes ovenfor. Ikke alene er tiden kommet, muligheden for at udnytte denne sammensmeltning som udgangspunkt for ny indsigt er også nu til stede med erkendelsen af teoriernes ekspressive dimension. Vi er nemlig nu i stand til at drage en anden konsekvens af dette end konstruktionismen, nemlig en ny form for realisme. Det er stadig virkeligheden, vi er forpligtet på, men det er ikke en forpligtelse til blot at repræsentere den, men at forstå dens potentiale, dens historiske overskud. Den klassiske metafysiske realisme var baseret på en (uerkendt) ontologisk dumpning, som vi nu kan erstatte med langt mere 
flydende begreber om verden, uden at vi derved mister hverken fodfæste eller kontakt med virkeligheden.

Den videnskabelige forståelse er, ligesom al anden forståelse, en begivenhed, der ikke forudsætter et fast forhold mellem ordene og resten af verden, eller mellem de teoretiske sætninger og den objektive virkelighed. Vi er med andre ord kommet til slutningen af den gamle drøm om entydig referens. Ingen begreber „kortlægger“ verden udtømmende og præcist. I sprogfilosofien har man længe talt om, at referens er ubestemmenlig i det abstrakte, og at den kun lader sig bestemme i konkrete sproghandlinger, der helt midlertidigt forbinder to eller flere mennesker i samtale. Ordene selv har ingen betydning; de har kun betydning i brug. Derfor kan man ikke sige, at ord giver direkte adgang til en ontologi. Det gælder også de sammensætninger af ord, som udgør teorier om verdens indretning og sammenhæng, at de ikke er modstandsløse veje til sandheden, men at de snarere er anråbelser af den, eller udvidelser af verden, arabesker på historien. Teoriernes acceptabilitet har derfor mere at gøre med vores erfaring med verden end med de ord, vi bruger til at tale om den i. Referensforholdet er og bliver uigennemsigtigt; og enhver forståelse er afhængig af, at der er en eller anden, der faktisk lige nu forstår.

De humanistiske teoriers betydning kan derfor ikke nivelleres til referens. Også i videnskabens verden er det mennesker, der skaber og oplever forståelse; der er ikke noget, der simpelthen opdages. Vi kan naturligvis opdage et nyt købmandsarkiv i et nyudgravet oldassyrisk hus i Anatolien, finde en ukendt komponists glemte nodeark, eller for den sags skyld genopdage Amerika. Men det ontologisk nye, eller de egentlige videnskabelige landvindinger opstår i og med en ny menneskelig erkendelse.

Når skellet mellem faktum og forståelse således bryder sammen, så har det nogle omfattende konsekvenser for vores opfattelse af „evidens“, eller belæg. Vi må naturligvis fortsat kræve belæg for vores udsagn om verden, empiriske belæg. Ikke alt lader sig sige, og uden belæg er ingen teorier overbevisende i længden. Men igen er det vigtigt at forstå, at belæg ikke er neutrale, teori-uafhængige observationer. Relationen mellem belæg og teori hviler på en implikation snarere end på referens. Det implikationelle forhold etableres inden for en helhed, der ikke er „,derude“ $i$ form af betydningsholisme, men som er en del af det teoretiske argument, som foregrebet ovenfor (jf. Quine 1992:13ff.). Sproget, inklusive det teoretiske sprog, infiltrerer vores opfattelse af virkeligheden i en grad, der gør det helt umuligt at forestille sig forskeren som en uafhængig opmåler af verden. Selv evidens er et spørgsmål om erfaring og om at kunne overbevise sine læsere eller tilhørere om, at der er en konsistens mellem belægget og helheden. Når ethvert belæg er relativt - i forhold til den etablerede teoretiske helhed - så er det ikke længere muligt at opretholde illusionen om en metafysisk realisme, en egentlig Objektivisme. Spørgsmålet om, hvad verden består af, giver kun mening i forhold til en bestemt beskrivelseshorisont. Holismen selv er teoretisk ikke empirisk.

Der er stadig et spørgsmål om sandhed, hvis vi skal leve op til en eller anden form for realistisk ambition, uden hvilken vi næppe kan have nogen videnskab. Eller hvis sandhed er blevet et for belastet ord, så er der, som Putnam (1990) siger det, stadig et udtalt ønske om at forstå verden ,rigtigt“. Men hvis vi har givet afkald på endelige (designative) teorier om verdens indretning, og i stedet ønsker at fremhæve de (ekspressive) tilføjelser til gældende selvforståelse, så er det klart, at det at forstå noget ,rigtigt“ ikke er det samme som at nå en fuldkommen sandhed, men at fremsætte et levedygtigt forslag til, hvordan verden kan forstås her og nu og under denne synsvinkel. Der er mere eller mindre accep- 
table teorier, mere eller mindre adækvate forbindelser mellem helhed og evidens, og mere eller mindre overbevisende argumenter. Argumentets styrke ligger ikke alene i dets egen konsistens, men også i dets kohærens med den menneskelige erfaring i øvrigt.

I en post-objektivistisk tidsalder er den videnskabelige sandhed ikke så meget et spørgsmål om uafhængigt bevis, som det er et spørgsmål om kohærens med erfaringen og om ,rimelighed“. Rimelighed i den forstand er et brud med forestillingen om den frit svævende rationelle tanke, der arbejdede uden for virkeligheden, som den fors $\emptyset$ gte at kontrollere intellektuelt og instrumentelt. Rimelighed er i stedet en form for rationalitet, der inkorporerer både intuition og værdisætning. Der er ingen kendsgerninger uden værdier, ingen historie uden valg.

\section{Videnskabelig ansvarlighed}

Det er ikke ualmindeligt at høre om forskningens frihed. Det er ofte parodieret $\mathrm{i}$ en forestilling om, at forskeren er totalt ligeglad med samfundet og resten af verden, blot han eller hun kan få lov at sidde i fred i sit elfenbenstårn og tænke stort og uforpligtende. Denne parodi er helt ude af trit med virkeligheden, og derfor er den ikke længere hverken effektiv eller morsom.

Forestillingen har i særlig grad drejet sig om den humanistiske forskning på universiteterne, mens det udviklingsarbejde, der er blevet udført på kemiske fabrikker eller i internationale astronomiske observatorier, a priori er blevet anset for værdifuldt. Det mest tragiske er imidlertid ikke, at skiftende ministre, folkeforførere og andre har betragtet den humanistiske forskning som en overflødig luksus, man kun opretholder af hensyn til en døende elite, ligesom Det Kongelige Teater og Statens Museum for Kunst. Det værste er, at humanisterne selv har mistet fornemmelsen af at bidrage til en helt afgørende fornyelse af det tankeberedskab, som alle må trække på, hvis de vil skrive ny historie.

Man kan se denne tragedie som udtryk for, at humanister (og det er stadig et meget omfattende udsnit af forskningsverdenen) har taget stereotyperne på sig. Antropologer har ofte dokumenteret, hvordan mennesker alle steder tager andres opfattelser af sig selv på sig, og dette er naturligvis blot et eksempel på den almene sandhed, at vi blandt andet bliver til i ,den andens“ blik. „Jeg“ opstår ved, at nogen giver mig navn og taler til mig som ,du“".

At de humanistiske videnskaber alligevel har bidraget med omfattende indsigt og begrebsfornyelse, er hævet over enhver tvivl, og det taler højt og tydeligt om det humanistiske potentiale selv i ulvetider. De forkætrede forskere har undervist, og hele tiden fået deres begreber skærpet eller forkastet af de kritiske studerende, der strømmer ind fra egnene uden for elfenbenstårnet; de har meddelt sig skriftligt, og set deres indsigter omsat $\mathrm{i}$ andres samtale. En væsentlig del af de teorier, der er fremsat gennem tiden, udg $\varnothing \mathbf{r}$ dagens ,,common sense“. Når det er blevet selvfølgeligt at tale om sådan noget som sprog og bevidsthed, økonomi og politik, samfund og uddannelse, så er det fordi disse teoretiske ,samlebetegnelser“ har svaret til dele af den virkelighed, man var fælles om. Kulturelle selvfølgeligheder opstår ikke i og med en kulturel essens eller findes som en naturlig kvalitet ved samfundet. De opstår i udvekslingen mellem mennesker og mellem mennesker og deres omgivelser. Humanister er centralt placerede i italesættelsen af denne udvekslingsproces, og dermed i dens fornyelse. 
Fornyelsen er dybt afhængig af forskningens frihed. Man kan sige, at det er en del af den menneskelige tankes natur, at den til enhver tid kan overskride det allerede givne. Tanken er fri i den forstand. Forskningens frihed indebærer en systematisk udnyttelse af tankens frihed, herunder en frihed til at vælge sin genstand, sin metode og sit mål. Men det overordnede sigte er klart: fornyelse af den kollektive forståelse af verdens indretning og historiens overskud. Når ethvert aldrig så moderne eller postmoderne samfund i denne globale tidsalder har brug for et universitet eller tilsvarende tænketanke, så er det, fordi der må findes et sted, hvor der kan tænkes nyt, uafhængigt af de kræfter, der i øvrigt netop har magten til at objektivere og realisere egne forestillinger. Videnskaben er på den måde altid ansvarlig over for sit samfund. Den garanterer mod stivnede objektiveringer.

Den videnskabelige ansvarlighed er imidlertid også en ansvarlighed over for virkeligheden. Selvom vi mere eller mindre frit kan konstruere vores analytiske objekter, så kan vi ikke gøre det uden en empirisk forankring i de verdener, der udgør rammen om det liv, vi vælger at studere. Vi kan ikke tillade os at overse empirien, selvom vores projekt er teoretisk. Den vilje til viden, der ligger i det humanistiske projekt, er ikke en vilje til kontrol over naturen, men til at gribe det menneskelige i flugten, at begribe dets flertydighed, og foregribe dets mulighed.

Af hensyn til vores muligheder for at levere alternative forståelser må vi som intellektuelle altid reagere mod at gå i ét med de herskende begreber; vi kan ikke (kun) være eksperter. Medmindre vi fastholder dette, så bliver vi selv ofre for ekspertvældet i vores daglige arbejde, hvor vi hele tiden måles på vores medieoptræden og vores signaler. Selvfølgelig er der områder, hvor vi kan levere ekspertsvar, men vi kan ikke lade os nøje med at svare på de spørgsmål, der allerede kan stilles. Vi må holde vågerne åbne for nytænkning, så der kan stilles uventede spørgsmål, til glæde for det samfund, der stadig har brug for en egentlig videnskab, der kan fortætte virkeligheden til nyt stof. En ansvarlig videnskab holder sig hele tiden denne ambition for $ø j e$.

\section{Millennium}

Tiden er kommet til at afslutte et kapitel, som begyndte med renæssancen. Erkendelsen af menneskets placering i centrum af historien gjorde det både frit og ansvarligt. Det er en erkendelse, der stadig er nødvendig, hvis vi skal udnytte det samfundsmæssige potentiale, som ligger i det videnskabelige arbejde. En anden nødvendig erkendelse er sammenhængen i det videnskabelige projekt. Det væsentligste i mine øjne er dels at erkende grænseløsheden i det videnskabelige objekt, og hermed de delvist arbitrære disciplinære grænser, dels at eksplicitere ethvert analytisk objekts uafsluttethed. Det menneskelige og det gælder hvad enten vi taler om det menneskeliges indhold eller dets udtryk - forandrer sig hele tiden i og med historien, og i og med erkendelsen. Det ved vi af erfaring. $\mathrm{Og}$ erfaringen er som nævnt den eneste domsinstans, vi har til at afgøre den relative gyldighed af vores viden.

Med et sådant objekt er det ikke længere muligt at operere med en forståelse af teorier som objektive afspejlinger af det menneskelige felt, det vil sige en forestilling om korrespondens, ej heller med et syn på teorier som faste størrelser. Tanken om simpelthen at opklare det i objektet iboende reducerer den teoretiske bestræbelse til at opdage det allerede givne; i stedet må sættes en ambition om at tilføje noget nyt, at bidrage ekspressivt 
til nye erkendelser, ved hjælp af en radikal fortolkning. At dette indebærer en nødvendighed af at leve med en mere flydende ontologi, end de klassiske teorier lod os formode, det er simpelthen et vilkår for de humanistiske videnskaber. Disse videnskabers potentiale findes netop her.

Teorier er med andre ord ikke længere blot udtryk for faste genrer, hvorigennem stadigt flere menneskelige forhold skal filtreres; de vokser ud af forskernes møde med verden, og ud af den begivenhed, som teoretisk forståelse er. I den forstand er den humanistiske videnskabelige praksis kongenial med sit objekt; også i den virkelige verden er ny forståelse noget, der opstår ved mødet mellem kendte kategorier og nye erfaringer, der gradvist bidrager til en ændring af kategoriernes betydning. I den forstand kan vi igen give Quine (1992) ret, når han siger, at teorier altid er underdetermineret af empirien; de hverken afspejler eller afklarer det empiriske, men samler det i en ny erkendelse.

For de humanistiske forskere er det nu opgaven at fastholde en teoretisk ambition, uden hvilken der ikke ville være tale om videnskab, og samtidig at udnytte det dynamiske potentiale, der knytter sig til enhver ny indsigt, der kan påvirke menneskers selvforståelse. Denne påvirkning indebærer ikke primært en udpegning af den gældende forståelses utilstrækkelighed, men en fremvisning af dens historiske tilfældighed. Denne fremvisning ligger latent i det teoretiske arbejde, som humanisterne udfører fra deres selvvalgte eksil i forhold til de herskende ideer. I eksilet tager forskeren en position som ,den radikale anden" i forhold til de menneskelige værdier og vilkår, der er under lup, og herfra er det muligt at opnå en uventet forståelse.

Ved at give udtryk for nye måder at forstå verden på, åbner videnskaben for nye historier. Deri ligger dens styrke og dens nødvendighed - også i det ny årtusind.

\title{
Note
}

1. Denne artikel er et let redigeret uddrag af min bog Viljen til Viden. En Humanistisk Grundbog, Gyldendal 1999.

\section{Litteratur:}

\author{
Barth, Fredrik \\ 1993 Balinese Worlds. Chicago: University of Chicago Press. \\ Cohen, Anthony \\ 1994 Self Consciousness. An Alternative Anthropology of Identity. London: Routledge. \\ Davidson, Donald \\ 1984 Inquiries into Truth and Interpretation. Oxford: Clarendon. \\ Hastrup, Kirsten \\ 1990 Videnskabens verden. Tre parabler over subjekt-objektforholdet. Stofskifte, Tidsskrift for \\ Antropologi 20:35-54. \\ 1995 A Passage to Anthropology. Between Experience and Theory: London: Routledge. \\ 1999 Viljen til Viden. En Humanistisk Grundbog. København: Gyldendal. \\ n.d. Theatres of Action. Human Agency in the Company of Shakespare. London. \\ (Under udgivelse).
}


Jensen, Jørgen

1992

Thomsens Museum. Historien om Nationalmuseet. København: Gyldendal.

Nielsen, Jørgen Juul (red.)

1996 Pico della Mirandola: Om Menneskets Værdighed. København: Museum Tusculanum Press.

Putnam, Hilary

1990 Realism With a Human Face. Cambridge, Mass.: Harvard University Press.

Quine, W. V.

1992 Pursuit of Truth. Cambridge, Mass.: Harvard University Press.

Rapport, Nigel

1993

Derse Worldviews in an English Village. Edinburgh: Edinburgh University Press.

1997

The Transcendent Individual. London: Routledge.

Taylor, Charles

1985

Human Agency and Language. Philosophical Papers vol. 1. Cambridge: Cambridge University Press. 